\title{
Perbedaan Tingkat Kecemasan Ibu Bersalin di Puskesmas dengan di Bidan Praktik Mandiri dan Hubungannya dengan Lama Persalinan
}

\author{
Fatihatul Hayati ${ }^{1}$, Rahmatina B. Herman ${ }^{2}$, Meilinda Agus ${ }^{3}$
}

\begin{abstract}
Abstrak
Kejadian kematian ibu lebih tinggi terjadi pada ibu yang bersalin dengan tindakan dibandingkan pada ibu yang bersalin normal. Rasa cemas yang tidak teratasi juga dapat menyebabkan persalinan berlangsung lebih lama dan harus diakhiri dengan tindakan. Lingkungan bersalin di rumah sakit dapat meningkatkan kecemasan ibu yang berakibat mengganggu kontraksi uterus sehingga tindakan harus dilakukan untuk mempercepat proses persalinan. Tujuan penelitian adalah mengetahui perbedaan tingkat kecemasan ibu bersalin di Puskesmas dan di Bidan Praktik Mandiri serta hubungannya dengan lama persalinan. Desain penelitian adalah crossectional terhadap 74 orang ibu bersalin yang dibagi menjadi dua kelompok yaitu ibu bersalin di Puskesmas dan ibu bersalin di Bidan Praktik Mandiri (BPM) dengan teknik consecutive sampling. Data dianalisis dengan uji t independen dan Chi-square dan hasilnya terdapat perbedaan signifikan dengan nilai $p<0,05$ dan terdapat hubungan antara tingkat kecemasan dengan lama persalinan dengan nilai $p<0,05$. Simpulan studi ini ialah ada perbedaan signifikan antara tingkat kecemasan ibu bersalin di Puskesmas dan di Bidan Praktik Mandiri, serta ada hubungan antara tingkat kecemasan dan lama persalinan.
\end{abstract}

Kata kunci: tingkat kecemasan, lama persalinan

\begin{abstract}
Maternal mortality rate is higher in assisted childbirth rather than that of natural childbirth. The unresolved anxiety can cause childbirth to last longer and lead to assisted childbirth. Childbirth environment at the hospital can increase maternal anxiety which results in disturbing uterine contraction so that action should be taken to speed up the delivery process. The objective of this study was to determine the difference of anxiety level between mothers who give birth at the Public Health Center and who give birth at Private Midwife Center and its relation on the period of labor. The study was conducted by cross-sectional design on 74 mothers in labor. They were divided into two groups: those who give birth at Public Health Center and those who give birth at Private Midwife Center with consecutive sampling technique. Data were then analyzed by conducting independent $t$ test and Chi-square. The result showed that the first group had higher average score of anxiety than the second group with $p$ value $<0.05$ and there was a relationship between the level of anxiety and the period of labor with $p$ value $p<0.05$. The conclusion is a significant difference between giving birth at Public Health Center and giving birth of Private Midwife Center and there was relationship between the level of anxiety and period of labor.
\end{abstract}

Keywords: anxiety level, period of labor

Affiliasi penulis: 1. Program Studi Magister S2 Kebidanan FK Unand (Fakultas Kedokteran Universitas Andalas Padang), 2. Bagian Fisiologi FK Unand 3. Poltekkes Padang

Korespondensi: Fatihatul Hayati,

Email: iha_hayati@yahoo.co.id Telp: 081367651148

\section{PENDAHULUAN}

Indikator keberhasilan pembangunan suatu negara dapat dilihat dari Angka Kematian Ibu (AKI), yang dipengaruhi oleh status kesehatan secara umum, 
pendidikan dan pelayanan kesehatan selama kehamilan dan melahirkan. AKI juga merupakan salah satu target yang telah ditentukan dalam Millenium Development Goals (MDGs) yang kelima, yaitu meningkatkan kesehatan ibu dimana target yang akan dicapai sampai tahun 2015 adalah mengurangi sampai tiga per empat resiko jumlah kematian ibu, yaitu 102 per 100.000 kelahiran hidup. ${ }^{1}$

Sasaran ibu bersalin di Kota Padang pada tahun 2012 adalah 18.457 dan melakukan persalinan dengan tenaga kesehatan $92,3 \%$ atau 17.027 ibu bersalin, angka ini sudah melebihi target (92\%), namun kasus kematian ibu di kota Padang tahun 2014 sebanyak 19 orang, meningkat dibandingkan tahun 2012 sebanyak 16 orang. Hasil penelitian memperlihatkan bahwa AKI lebih tinggi terjadi pada ibu yang cara persalinannya ditolong dengan tindakan dibandingkan ibu yang persalinannya berlangsung spontan. Kematian ibu tersebut disebabkan oleh perdarahan $(32 \%)$, eklampsia $(14 \%)$, partus lama $(12 \%)$, infeksi $(11 \%)$, abortus (14\%), penyakit jantung (5\%), dan lain-lain (12\%). Perdarahan ibu terjadi karena retensi plasenta, anemia berat, partus lama, dan lainnya. ${ }^{2,3}$

Penyebab kematian ibu ketiga di Sumatera Barat adalah partus lama, yaitu persalinan yang berlangsung lebih dari 24 jam. Permasalahan harus dikenali dan diatasi sebelum batas waktu 24 jam tercapai. Sebagian besar partus lama menunjukkan perpanjangan kala I. Sebab utama dari partus lama adalah disproporsi feto pelvik, malpresentasi dan malposisi serta kerja uterus yang tidak efisien, termasuk serviks yang kaku. Sementara partus lama dapat mengakibatkan perdarahan pada ibu inpartu maupun postpartum. Disamping itu, pada bayi partus lama dapat pula menyebabkan terjadinya asfiksia, yang merupakan penyebab terbesar kematian bayi di Sumatera Barat. ${ }^{2,4}$

Faktor emosi atau psikologis terjadinya partus lama adalah ketakutan dan kecemasan ibu yang tidak teratasi selama melahirkan. $65 \%$ kejadian partus lama disebabkan karena kontraksi uterus yang tidak efisien sebagai respon terhadap kecemasan sehingga menghambat aktifitas uterus. ${ }^{5,6}$
Salah satu penyebab terjadinya partus lama adalah respon stres yang menempati urutan paling atas di antara lainnya. Kondisi ini terjadi karena ibu bersalin akan menghadapi berbagai masalah dalam adaptasinya selama proses persalinan, diantaranya rasa nyeri saat kontraksi, ketakutan akan ketidakmampuan dalam menangani masalah yang akan terjadi, ketegangan dan hiperventilasi. ${ }^{7}$

Sekitar $6 \%$ dari populasi umum mengalami gangguan cemas, generalized anxiety disorder (GAD) merupakan gangguan yang paling sering ditemui, terjadi pada $2-4 \%$ populasi. $^{8}$ Permasalahan psikologis yang dialami ibu bersalin dalam menghadapi persalinan yaitu cemas $(52 \%)$ dan ragu akan kemampuannya mengatasi rasa nyeri $(43 \%){ }^{9}$ Kecemasan dan ketakutan yang dialami oleh ibu bersalin terutama primipara dapat memperpanjang durasi persalinan dan meningkatkan kejadian persalinan dengan tindakan, yaitu persalinan dengan seksio sesarea (OR 26,9 Cl 95\%) dan vakum ekstraksi (OR 4,5 Cl 95\%). Ibu yang pernah melahirkan dan mengalami cemas pada saat melahirkan merupakan saat-saat tidak menyenangkan dalam hidupnya. ${ }^{6}$

Kecemasan yang tidak teratasi juga merupakan prediktor terjadinya nyeri selama melahirkan yang akan mempengaruhi kesehatan ibu dan bayi. Sebaliknya nyeri selama melahirkan juga menyebabkan timbulnya kecemasan, sehingga antara stres, kecemasan, ketakutan dan nyeri merupakan siklus yang berkesinambungan. Sementara pasien yang mengalami nyeri empat kali lebih cemas dibandingkan dengan pasien yang tidak mengalami nyeri. $^{10,11}$

Fenomena yang berkembang selama ini para petugas kesehatan baik dokter, bidan, maupun perawat kebanyakan hanya memperhatikan kondisi fisik dibandingkan dengan pemenuhan kebutuhan kondisi psikis dari ibu dalam menjelang persalinan dan selama persalinan. Kondisi ini dapat memicu terjadinya kecemasan dan rasa takut pada ibu yang sedang melahirkan. ${ }^{12}$

Kemajuan persalinan dipengaruhi oleh beberapa faktor, salah satunya adalah psikologis ibu. Psikologis ibu yang terganggu akibat ketakutan atau 
kecemasan selama bersalin dapat menghambat proses bersalin. Perbedaan waktu persalinan antara wanita yang mengalami ketakutan dengan yang tidak mengalami ketakutan adalah 1 jam 32 menit. ${ }^{13}$

Proses persalinan merupakan pengalaman fisik yang menimbulkan sensasi nyeri. Nyeri persalinan merupakan suatu peristiwa yang komplek dan subyektif, merupakan interaksi antara faktor fisiologis, psikologis, lingkungan dan budaya serta interpretasi terhadap stimulus persalinan. Kecemasan dan ketakutan menurunkan kemampuan coping terhadap nyeri. Kecemasan yang muncul selama proses persalinan diakibatkan oleh beberapa hal diantaranya kecemasan terhadap perjalanan proses persalinan, cemas terhadap kondisi janin dan cemas terhadap keberhasilan proses persalinan. ${ }^{11}$

Kecemasan bisa terjadi karena pengalaman baik pengalaman bersalin sebelumnya atau pengalaman buruk kerabat atau teman tentang persalinan dan kenyataan bahwa kehamilan yang beresiko juga menyebabkan ibu tidak siap menghadapi persalinan. Tenaga medis dan situasi tempat yang tidak bersahabat dapat mempengaruhi rasa nyaman ibu untuk melahirkan. Terkadang hambatan psikologis lebih besar pengaruhnya dibandingkan fisik. Sering juga terjadi gangguan fisik maupun psikologis berpadu menjadi lingkaran setan yang sulit diputuskan, mekanisme ini disebut incoordinate uterine action. Tindakan untuk mengupayakan rasa nyaman dapat berupa upaya menciptakan suasana yang nyaman dalam kamar bersalin, memberi sentuhan, memberi penanganan nyeri tanpa obat dan yang paling penting berada di sisi ibu. $^{14,15}$

Pada jaman dahulu, perempuan belajar tentang persalinan dari ibu dan saudara perempuannya. Persalinan berlangsung di rumah dengan situasi yang familiar dengan mereka sehingga memberikan suasana yang nyaman dan mengurangi kecemasan. Selama proses persalinan, mereka akan ditemani oleh suami dan anggota keluarga lain yang diinginkannya, yang terus memberikan dukungan dan membesarkan hati mereka dalam menjalani proses tersebut. Pada masa itu bidan komunitas yang menolong hampir sebagian besar persalinan. ${ }^{16}$
Orientasi pelayanan kebidanan pada abad kedua puluh mengalami perubahan ke arah medikalisasi, maka pertolongan persalinan yang awalnya berlangsung di rumah dialihkan ke rumah sakit. Tentunya nilai-nilai yang dimiliki oleh perempuan sebelumnya tidak dapat diterapkan seluruhnya di rumah sakit. Para provider memberikan pelayanan dan dukungan namun tidak dapat secara utuh karena perhatian mereka terbagi karena begitu banyak klien yang menjadi tanggung jawabnya. ${ }^{16}$ Demikian juga dengan peran keluarga yang tidak optimal dalam persalinan di rumah sakit, karena keterbatasan ruang bersalin dan jumlah pasien bersalin.

Beberapa ibu bersalin merasa cemas di lingkungan rumah sakit dan kondisi ini dapat memperlambat kontraksi, membuat persalinan lebih lama dan tindakan terpaksa harus dilakukan untuk mempercepat proses persalinan. Ibu yang bersalin di rumah sakit mungkin juga tidak bisa mendapatkan perawatan dari bidan yang sesuai dengan keinginan selama proses persalinannya. Berbeda dengan persalinan di praktik bidan yang biasanya dirancang agar terlihat seperti rumah dengan perawatan dari seorang bidan yang sama. ${ }^{15}$

Teori lingkungan terapetik meliputi psikologi lingkungan (efek psikososial dari lingkungan), psychoneuroimmunology (efek lingkungan terhadap sistem imun); neuroscience (bagaimana pemikiran arsitektur atau desain ruang) dapat mempengaruhi kenyamanan ibu bersalin selama proses persalinannya. Fasilitas pelayanan kesehatan untuk pasien diharapkan dapat meningkatkan kesehatan, keamanan, dan hubungan sosial yang normal dan tidak terkesan mengisolasi. Desain lingkungan yang terapetik diperlukan untuk pasien di lingkungan rumah sakit. $^{17}$

Seorang wanita hamil berisiko rendah harus melahirkan di tempat yang membuat wanita merasa aman dan nyaman. Tempat tersebut antara lain di rumah, bidan praktek mandiri atau klinik bersalin. Tempat tersebut harus merupakan sebuah tempat dimana semua perhatian dan perawatan difokuskan pada kebutuhan dan keamanannya, sedekat mungkin dengan lingkungan yang dikenalnya. Hal ini penting karena persalinan merupakan situasi yang penuh 
dengan kecemasan dan dipenuhi oleh pikiran negatif yang berakibat pada kestabilan emosi ibu bersalin, sehingga akan berpengaruh juga pada proses persalinan. Keberadaan suami dan keluarga serta dukungan lingkungan selama proses persalinan akan memberikan rasa aman serta dapat mengurangi rasa nyeri dan persalinan berlangsung lebih cepat. ${ }^{18,19}$

Asuhan kebidanan pada ibu bersalin normal merupakan salah satu pelayanan yang ditanggung dalam program Jaminan Kesehatan Nasional (JKN) yang diberikan di fasilitas kesehatan tingkat pertama, meliputi Puskesmas, Klinik dan Bidan Praktik Mandiri yang bekerja sama dengan Badan Penyelenggara Jaminan Sosial (BPJS). ${ }^{20}$ Puskesmas sebagai fasilitas kesehatan milik pemerintah maupun Bidan Praktik Mandiri (BPM) sebagai fasilitas kesehatan swasta dituntut untuk dapat memberikan pelayanan optimal dalam asuhan kebidanan, termasuk di dalamnya penyediaan sarana dan prasarana, tenaga kesehatan/ bidan, dan lingkungan yang kondusif untuk asuhan persalinan normal, sehingga persalinan tidak menjadi patologis, kesakitan dan kematian ibu dapat dikurangi.

Studi pendahuluan yang dilakukan pada 10 orang ibu bersalin di Puskesmas dan 10 orang ibu bersalin di Bidan Praktik Mandiri (BPM), didapatkan hasil bahwa pada ibu bersalin di Puskesmas, 2 orang (20\%) mengalami kecemasan ringan, 4 orang $(40 \%)$ mengalami kecemasan sedang dan 4 orang (40\%) mengalami kecemasan berat, dengan lama persalinan 7 orang $(70 \%)$ normal dan 3 orang (30\%) memanjang. 2 orang ibu bersalin kala I memanjang dirujuk atas indikasi partus lama dan gawat janin. Sementara di BPM didapatkan ibu bersalin dengan tingkat kecemasan ringan 3 orang $(30 \%)$ dan ibu bersalin dengan tingkat kecemasan sedang 7 orang (70\%). Adapun lama persalinan kala I di BPM didapat bahwa 9 orang $(90 \%)$ normal dan 1 orang $(10 \%)$ memanjang.

\section{METODE}

Penelitian analitik dengan rancangan cross sectional study comparative ini telah dilakukan di seluruh Puskesmas Perawatan di kota Padang dan empat Bidan Praktik Mandiri (BPM) Kota Padang yang rerata persalinan perbulannya cukup banyak, bersedia dijadikan tempat penelitian dan lokasinya terjangkau. Puskesmas dan BPM menyediakan fasilitas Badan Penyelenggara Jaminan Sosial (BPJS) Kesehatan. Penelitian dilaksanakan November 2014 November 2015. Sampel diambil dengan consecutive sampling terhadap 74 orang responden Ibu bersalin normal primigravida.

Data dianalisis dengan uji $t$ independen untuk mengetahui perbedaan tingkat kecemasan ibu bersalin di Puskesmas dengan di Bidan Praktik Mandiri dan Chi-square untuk mengetahui hubungan tingkat kecemasan dengan lama persalinan.

HASIL

Tabel 1. Gambaran karakteristik responden

\begin{tabular}{lccccc}
\hline Karakteristik & \multicolumn{2}{c}{ Puskesmas } & \multicolumn{2}{c}{ BPM } & p \\
\cline { 2 - 6 } Responden & $\mathbf{f}$ & $\%$ & $\mathbf{f}$ & $\%$ & \\
\hline Umur & & & & & 0,191 \\
\hline$<20$ Tahun & 13 & 35,1 & 7 & 18,9 & \\
20-35 Tahun & 24 & 64,9 & 30 & 81,1 & \\
\hline Pendidikan & & & & & 0,416 \\
\hline Menengah & 30 & 81,1 & 26 & 70,3 & \\
Tinggi & 7 & 18,9 & 11 & 29,7 & \\
\hline Pekerjaan & & & & & 0,752 \\
\hline Bekerja & 5 & 13,5 & 7 & 18,9 & \\
Tidak Bekerja & 32 & 86,5 & 30 & 81,1 & \\
\hline Penghasilan & & & & & 1,000 \\
\hline < UMR & 7 & 18,9 & 6 & 16,2 & \\
$\geq$ UMR & 30 & 81,1 & 31 & 83,8 & \\
\hline Suku & & & & & 1,000 \\
\hline Matrilineal & 30 & 81,1 & 30 & 81,1 & \\
Patrilineal & 7 & 18,9 & 7 & 18,9 & \\
\hline Lama Menikah & & & & & 0,100 \\
\hline$<1$ Tahun & 25 & 67,6 & 17 & 45,9 & \\
$\geq 1$ Tahun & 12 & 32,4 & 20 & 54,1 & \\
\hline Frekuensi ANC & & & & & 1,000 \\
\hline < 4 Kali & 7 & 18,9 & 8 & 21,6 & \\
< 4 Kali & 30 & 81,1 & 29 & 78,4 & \\
\hline Senam Hamil & & & & & 1,000 \\
\hline Pernah & 12 & 32,4 & 13 & 35,1 & \\
Tidak Pernah & 25 & 67,6 & 24 & 64,9 & \\
\hline & & & & & \\
\hline
\end{tabular}


Tabel 2. Perbedaan dukungan emosional yang diberikan kepada ibu bersalin di puskesmas dengan di BPM

\begin{tabular}{llllll}
\hline Dukungan & \multicolumn{2}{l}{ Puskesmas } & \multicolumn{2}{l}{ BPM } & p \\
\cline { 2 - 5 } Emosional & $\mathbf{f}$ & $\%$ & $\mathbf{f}$ & $\%$ & \\
\hline Baik & 3 & 8,1 & 19 & 51,4 & 0,001 \\
Kurang Baik & 34 & 91,9 & 18 & 48,6 & \\
\hline Jumlah & 37 & 100 & 37 & 100 & \\
\hline
\end{tabular}

Tabel 3. Hubungan dukungan emosional yang diberikan kepada ibu bersalin dengan lama persalinan

\begin{tabular}{llllll}
\cline { 1 - 4 } Dukungan & \multicolumn{2}{l}{ Normal } & \multicolumn{2}{c}{ Memanjang } & p \\
\cline { 2 - 5 } Emosional & $\mathbf{f}$ & $\%$ & $\mathbf{f}$ & $\%$ & \\
\hline Baik & 18 & 38,3 & 4 & 14,8 & \multirow{2}{*}{0,062} \\
Kurang Baik & 29 & 61,7 & 23 & 85,2 & \\
\hline Jumlah & 37 & 100 & 37 & 100 & \\
\hline
\end{tabular}

Tabel 4. Hubungan dukungan emosional kepada ibu bersalin dengan tingkat kecemasan

\begin{tabular}{llllllll}
\hline Dukungan & \multicolumn{2}{c}{ Ringan } & \multicolumn{2}{c}{ Sedang } & \multicolumn{2}{c}{ Berat } & p \\
\cline { 2 - 7 } Emosional & $\mathbf{f}$ & $\%$ & $\mathbf{f}$ & $\%$ & $\mathbf{f}$ & $\%$ & \\
\hline Baik & 18 & 43,9 & 1 & 7,1 & 3 & 15,8 & \multirow{2}{*}{0,010} \\
Kurang Baik & 23 & 56,1 & 13 & 92,9 & 16 & 84,2 & \\
\hline Jumlah & 41 & 100 & 14 & 100 & 19 & 100 & \\
\hline
\end{tabular}

Tabel 5. Perbedaan lingkungan tempat persalinan di puskesmas dengan di BPM

\begin{tabular}{lccccc}
\hline Lingkungan & \multicolumn{2}{c}{ Puskesmas } & \multicolumn{2}{c}{ BPM } & p \\
\cline { 2 - 6 } Bempat & \multicolumn{1}{c}{ f } & $\%$ & $\mathbf{f}$ & $\%$ & \\
\cline { 2 - 6 } & 21 & 56,8 & 29 & 78,4 & 0,082 \\
Kaik & 16 & 43,2 & 8 & 21,6 & \\
\hline Jumlah & 37 & 100 & 37 & 100 & \\
\hline
\end{tabular}

Tabel 6. Hubungan lingkungan tempat persalinan dengan lama persalinan

\begin{tabular}{lccccc}
\hline Lingkungan & \multicolumn{2}{c}{ Normal } & \multicolumn{2}{c}{ Memanjang } & p \\
\cline { 2 - 5 } Tempat & $\mathbf{f}$ & $\%$ & $\mathbf{f}$ & $\%$ & \\
Bersalin & & & & & \\
\hline Baik & 38 & 80,9 & 12 & 44,4 & \multirow{2}{*}{0,003} \\
Kurang Baik & 9 & 19,1 & 15 & 55,6 & \\
\hline Jumlah & 47 & 100 & 27 & 100 & \\
\hline
\end{tabular}

Tabel 7. Hubungan lingkungan tempat persalinan dengan tingkat kecemasan

\begin{tabular}{lrrrrrrrr}
\hline Lingkungan & \multicolumn{3}{c}{ Ringan } & \multicolumn{3}{c}{ Sedang } & \multicolumn{3}{c}{ Berat } & \\
\cline { 2 - 6 } $\begin{array}{l}\text { Bempat } \\
\text { Bersalin }\end{array}$ & $\mathbf{f}$ & $\%$ & $\mathbf{f}$ & $\%$ & $\mathbf{f}$ & $\%$ & $\mathbf{p}$ \\
\hline Baik & 37 & 90,2 & 9 & 64,3 & 4 & 21,1 & \multirow{2}{*}{0,001} \\
Kurang Baik & 4 & 9,8 & 5 & 35,7 & 15 & 78,9 & \\
\hline Jumlah & 41 & 100 & 14 & 100 & 19 & 100 & \\
\hline
\end{tabular}

Tabel 8. Perbedaan tingkat kecemasan ibu bersalin di puskesmas dengan di BPM

\begin{tabular}{lccccc}
\hline $\begin{array}{c}\text { Tempat } \\
\text { Persalinan }\end{array}$ & Mean & SD & SE & N & p \\
\hline Puskesmas & 23,7 & 8,76 & 1,440 & 37 & \\
BPM & 17,76 & 8,62 & 1,417 & 37 & \\
\hline
\end{tabular}

Tabel 9. Perbedaan lama persalinan di puskesmas dengan di BPM

\begin{tabular}{|c|c|c|c|c|c|}
\hline \multirow{2}{*}{$\begin{array}{l}\text { Lama } \\
\text { Persalinan }\end{array}$} & \multicolumn{2}{|c|}{ Puskesmas } & \multicolumn{2}{|c|}{ BPM } & \multirow{2}{*}{$\mathbf{P}$} \\
\hline & $f$ & $\%$ & $f$ & $\%$ & \\
\hline Normal & 19 & 40,4 & 28 & 59,6 & \multirow{2}{*}{0,030} \\
\hline Memanjang & 18 & 66,7 & 9 & 33,3 & \\
\hline
\end{tabular}

Tabel 10. Hubungan antara tingkat kecemasan dan lama persalinan

\begin{tabular}{|c|c|c|c|c|c|}
\hline \multirow{3}{*}{$\begin{array}{l}\text { Tingkat } \\
\text { Kecemasan }\end{array}$} & \multicolumn{4}{|c|}{ Lama Persalinan } & \multirow[t]{3}{*}{$\mathbf{p}$} \\
\hline & \multicolumn{2}{|c|}{ Normal } & \multicolumn{2}{|c|}{ Memanjang } & \\
\hline & $f$ & $\%$ & $f$ & $\%$ & \\
\hline Ringan & 36 & 76,6 & 5 & 18,5 & \\
\hline Sedang & 9 & 19,1 & 5 & 18,5 & 0,001 \\
\hline Berat & 2 & 4,3 & 17 & 63,0 & \\
\hline Jumlah & 47 & 100 & 27 & 100 & \\
\hline
\end{tabular}

\section{PEMBAHASAN}

Perbedaan Tingkat Kecemasan lbu Bersalin di Puskesmas dengan di Bidan Praktik Mandiri (BPM)

Hasil penelitian menggambarkan bahwa rerata tingkat kecemasan ibu bersalin di Puskesmas lebih tinggi dibandingkan dengan tingkat kecemasan ibu bersalin di Bidan Praktik Mandiri (BPM). 
Berdasarkan uji statistik didapat nilai $p<0,05$, maka disimpulkan bahwa ada perbedaan tingkat kecemasan ibu bersalin di Puskesmas dengan di Bidan Praktik Mandiri (BPM).

Perbedaan tingkat kecemasan dalam penelitian ini dikarenakan adanya perbedaan dukungan emosional yang ibu dapatkan selama persalinan dan terdapat hubungan antara dukungan emosional yang didapatkan ibu selama persalinan dengan tingkat kecemasan ibu bersalin. Pendamping persalinan sangat dibutuhkan oleh ibu bersalin. pendamping tersebut dapat berperan dengan cara memberikan sentuhan, hiburan dan dorongan untuk mendukung ibu saat proses persalinan. Pendamping ibu saat proses persalinan sebaiknya adalah orang yang peduli pada ibu dan yang paling penting adalah orang yang diinginkan ibu untuk mendampingi ibu selama proses persalinan. $^{21,22}$

Salah satu penyebab tingginya AKI secara umum yaitu kurangnya perhatian dari keluarga, khususnya peran serta suami dalam proses kehamilan dan persalinan. Padahal suami sangat berperan dalam memberikan dukungan untuk membantu menenangkan kondisi fisik maupun psikis seorang istri. $^{23}$

Dukungan yang membawa dampak positif adalah dukungan yang bersifat fisik dan emosional. Dukungan tersebut meliputi beberapa aspek seperti menggosok punggung ibu, memegang tangannya, mempertahankan kontak mata, ibu ditemani oleh orang-orang yang ramah, dan ibu tidak menjalani proses persalinan sendirian. ${ }^{21}$

Studi lain tentang sentuhan persalinan membuktikan bahwa dengan sentuhan persalinan $56 \%$ lebih sedikit yang mengalami tindakan Seksio Sesarea, pengurangan penggunaan anestesi epidural hingga $85 \%, 70 \%$ lebih sedikit kelahiran dibantu forceps, $61 \%$ penurunan dalam penggunaan oksitosin, durasi persalinan yang lebih pendek $25 \%$ dan risiko komplikasi pada neonatus menurun $58 \%{ }^{16}$

Sentuhan dalam persalinan dapat mengurangi kecemasan, mengurangi nyeri dan meningkatkan kenyamanan, mengalami waktu persalinan secara signifikan lebih pendek, tinggal di rumah sakit lebih singkat dan kejadian depresi postpartum lebih rendah.
Touch Research Institute juga melaporkan bahwa wanita yang dipijat pasangannya merasa kurang tertekan, mengalami nyeri persalinan yang kurang dan memiliki stres dan tingkat kecemasan yang lebih rendah. Ibu yang dipijat ringan mengalami waktu persalinan secara signifikan lebih pendek, tinggal di rumah sakit lebih singkat dan depresi postpartum kurang. ${ }^{6}$

\section{Hubungan antara Tingkat Kecemasan dengan Lama Persalinan}

Hasil penelitian ini dapat disimpulkan bahwa terdapat hubungan antara tingkat kecemasan dengan lama persalinan di Puskesmas dan Bidan Praktik Mandiri Kota Padang dengan nilai $p=0,001$ ( $p<$ $0,05)$. Hubungan tersebut diperkuat dengan adanya perbedaan lama persalinan antara ibu bersalin di Puskesmas dengan di BPM.

Tingkat kecemasan ibu bersalin akan mempengaruhi lama persalinan, karena perasaan cemas yang dialami oleh ibu selama persalinan dapat merangsang hipotalamus sebagai pusat sistem limbik yang mengatur emosional. Hipotalamus akan merangsang kerja sistem saraf simpatis sehingga terjadi vasokontriksi pada organ dan jaringan, termasuk pada uterus, akibatnya asupan darah ke uterus berkurang sehingga oksigen dan nutrisi ke jaringan dan sel otot uterus tidak adekuat. Hal ini akan mengganggu metabolisme sel otot uterus sehingga energi yang dihasilkannya pun berkurang yang pada akhirnya menyebabkan gangguan pada kontraksi uterus. Jika kontraksi uterus terganggu, maka persalinan akan berlangsung lebih lama.

Kecemasan mempunyai reaksi neurofisiologis yaitu memacu pengeluaran adrenalin. Adrenalin akan memberi pengaruh vasokontriksi pembuluh darah uterus sehingga vaskularisasi berkurang yang berakibat berkurangnya kekuatan kontraksi otot rahim. Ibu bersalin yang cemas akan mengalami perpanjangan waktu persalinan hingga 12,5 kali dibandingkan dengan ibu bersalin yang bisa mengatasi kecemasannya. ${ }^{24,25}$

Penelitian yang berkaitan dengan kejadian persalinan lama, 65\% disebabkan karena kontraksi uterus yang tidak efisien. Disfungsional kontraksi 
uterus sebagai respon terhadap kecemasan sehingga menghambat aktifitas uterus. Respon tersebut adalah bagian dari komponen psikologis, sehingga dapat dinyatakan bahwa faktor psikologis mempunyai pengaruh terhadap terjadinya gangguan proses persalinan. ${ }^{26}$

Kecemasan pada ibu bersalin Kala I bisa berdampak meningkatnya sekresi adrenalin. Salah satu efek adrenalin adalah konstriksi pembuluh darah sehingga suplai oksigen ke janin menurun. Penurunan aliran darah juga menyebabkan melemahnya kontraksi rahim dan berakibat memanjangnya proses persalinan. Tidak hanya sekresi adrenalin yang meningkat tetapi sekresi ACTH (Adrenocorticotropic hormone) juga meningkat, menyebabkan peningkatan kadar kortisol serum dan gula darah. Kecemasan dapat timbul dari reaksi seseorang terhadap nyeri. Hal ini akan meningkatkan aktifitas saraf simpatik dan meningkatkan sekresi katekolamin. Sekresi katekolamin yang berlebihan akan menimbulkan penurunan aliran darah ke plasenta sehinga membatasi suplai oksigen serta penurunan efektifitas dari kontraksi uterus yang dapat memperlambat proses persalinan. ${ }^{27}$

Kekhawatiran yang teramat sangat pun bisa membuat otot-otot, termasuk otot di jalan lahir, bekerja berlawanan arah, karena dilawan oleh ibu yang kesakitan. Akibatnya, jalan lahir menyempit dan proses persalinan berjalan lebih lama dan sangat menyakitkan, bahkan bisa sampai terhenti. Hormon yang dilepas sebagai respon terhadap stres juga dapat menyebabkan distosia. Sumber stres bervariasi pada setiap individu, tetapi nyeri dan tidak adalah dua faktor yang berpengaruh. Apabila rasa cemas yang berlebihan akan menyebabkan dilatasi normal serviks sehingga terjadi persalinan yang lama dan meningkatkan persepsi nyeri. Kecemasan, ketakutan dan kesendirian, stress yang berlebihan dapat menyebabkan peningkatan jumlah hormon yang berhubungan dengan stres seperti $\beta$ endorphin, adrenokortikotropik, kortisol dan epineprin. Hormonhormon tersebut bekerja pada otot polos uterus. Peningkatan kadar hormon tersebut dapat menurunkan kontraktilitas uterus sehingga dapat meyebabkan persalinan yang lama. ${ }^{28}$

\section{UCAPAN TERIMA KASIH}

Terima kasih kepada Kepala dan Staf Puskesmas Lubuk Buaya, Puskesmas Nanggalo, Puskesmas Air Dingin, Puskesmas Seberang Padang, Puskesmas Pauh, Puskesmas Bungus, Puskesmas Padang Pasir dan Bidan Praktik Mandiri Elly Vambo, Bidan Praktik Mandiri Rika Hardi serta Bidan Praktik Mandiri Halimatunsakdiyah yang telah membantu penyelesaian tesis ini.

\section{DAFTAR PUSTAKA}

1. Kementerian Kesehatan Republik Indonesia. Survei demografi dan kesehatan Indonesia (SDKI) tahun 2013. Jakarta; 2013.

2. Dinas Kesehatan Kota Padang. Profil kesehatan Kota Padang tahun 2012. Padang; 2013.

3. Mariati, Ulvi, Agus Z, Sulin D, Masrul, Amri Z, et al. Studi kematian ibu dan kematian bayi di Provinsi Sumatera Barat. Jurnal Kesehatan Masyarakat Nasional. 2011;5(6) (diunduh 23 Februari 2015). Tersedia dari: URL: HYPERLINK http://download.portalgaruda.org/article.php?article

4. Kementerian Kesehatan Republik Indonesia Rencana aksi percepatan penurunan angka kematian ibu di Indonesia. Jakarta; 2013.

5. Dolea C, Abouzahr C. Global burden of obstructed of labour in the year 2000. WHO; 2003 (diunduh 12 Maret 2015). Tersedia dari: URL: HYPERLINK http://www.who.int/healthinfo/statistics/bod obstruc tedlabour.pdf

6. Pairman S. Midwifery: preparation for practice. Edisi ke-2. Australia; 2011.

7. Brayshaw E. Senam hamil \& nifas: pedoman praktis bidan. Jakarta; 2007.

8. Katona, Cornelius, Cooper C, Robertson M. At a glance psikiatri. Edisi Ke-4. Jakarta; 2012.

9. Flood LP, Brown ST, Douglas C. Womens evaluation of intrapartum nonpharmalogical pain relief methods used during labor. The Journal of Perinatal Education. 2001;10(3):3, 1-8 (diunduh 23 Februari 2015). Tersedia dari: URL: HYPERLINK https://www.clinicalkey.com/nursing/\#!/content/jour nal/1-s2.0-S1574626715001068

10. Thompson T, Keogh E, French CC, Davis R. Anxiety sensitifity and pain: generalisability across 
noxious stimuli. J. Pain. 2008 (diunduh 23 Februari 2015). Tersedia dari: URL: HYPERLINK http://research.gold.ac.uk/4294/1/Thompson et al 2008.pdf

11. Baesdo K. Association between generalized anxiety levels and pain in a community sample: evidence for diagnostic specificity. Journal of Anxiety Disorders. 2009; 23(5):684-93 (diunduh 14 Maret 2015). Tersedia dari: URL: HYPERLINK http://www.ncbi.nlm.nih.gov/pubmed/19278819

12. Dahro A. Psikologi kebidanan: analisis perilaku wanita untuk kesehatan. Jakarta; 2012.

13. Adams S, Eberhard-Gran M, Es Klid A. Fear of childbirth and duration of laboour; a study of women with intended vaginal delivery. BJOG. 2012;10,1471-0528 (diunduh 15 Maret 2015) Tersedia dari: URL: HYPERLINK http://www.ncbi. nlm.nih.gov/pubmed/22734617

14. Jensen MD, Lowdermilk DL, Bobak IM. Maternity nursing. Edisi ke-4. Mosby; 1995.

15. Danuatmaja B, Meiliasari M. Persalinan normal tanpa rasa sakit. Jakarta; 2008.

16. Green J, Amis A, Barbara A. Continuous labor support. Journal of Perinatal Education. 2007;16: 25-28 (diunduh 15 Maret 2015). Tersedia dari: URL: HYPERLINK http://www.ncbi.nlm.nih.gov/ pmc/articles/PMC1948096

17. Sercekus $P$, Okumus, H. Fears associated with childbirth among nulliparous. Turkey, Midwifery. 2009;25(2):155-62 (diunduh 15 Maret 2015) Tersedia dari: URL: HYPERLINK http://www.ncbi.nlm.nih.gov/pubmed/17600599

18. Taylor. Fundamental of Nursing, The Art and Science of Nursing Care. Edisi ke-4. Philadelphia: Lippincott. 2004, 102:E29.
19. Amir AM. Kiat-kiat melahirkan nyaman tanpa rasa sakit yang menakutkan. Jogjakarta; 2010.

20. BPJS Kesehatan. Panduan praktis pelayanan kebidanan dan neonatal. Jakarta; 2014.

21. Henderson, C. Buku ajar konsep kebidanan. Jakarta. 2006.

22. Rukiyah Y. Konsep kebidanan. Jakarta; 2011.

23. Tursilowati SY. Pengaruh peran serta suami terhadap tingkat kecemasan ibu hamil dalam menghadapi proses persalinan di Desa Jepat Lor Kecamatan Tayu Kabupaten Pati. Yogyakarta; 2007

24. Sarwinanti. Efektifitas pemberian paket persiapan pendamping persalinan terhadap lama persalinan dan tingkat kecemasan ibu bersalin di Yogyakarta. Jakarta: Universitas Indonesia; 2011.

25. Aprilia Y. Hipnostetri rileks, nyaman dan aman saat hamil dan melahirkan. Jakarta; 2010.

26. Kirby RS, Frost J. Maternal And newborn outcomes in planned home birth vs planned hospital births: a metaanalysis. American Journal of Obstetrics and Gynecology. 2011;204(4):e18-20 (diunduh 14 Maret 2015). Tersedia dari: URL: HYPERLINK http://www.ncbi.nlm.nih.gov/ pubmed/ $\underline{21458613}$

27. Janssen PA, Saxell L, Page LA, Klein MC, Liston RM, Lee SK. Outcomes Of planned home birth with registered midwife versus planned hospital birth with midwife or physician. Canadian Medical Association Journal. 2009;181(6-7):377-83 (diunduh 14 Maret 2015). Tersedia dari: URL: HYPERLINK http://www.ncbi.nlm.nih.gov/pubmed/ 19720688

28.Bobak IM, Lowdermilk DL, Jensen MD, Perry SE. Buku ajar keperawatan maternitas. Edisi ke-4. Alih Bahasa: Maria AW,Peter IN. Jakarta; 2005. 